\title{
THE FLEXIBILITY RULE IN ADMINISTRATIVE LAW
}

\begin{abstract}
ADAM PERRY
ABSTRACT - Administrative officials are permitted to have policies as to the exercise of their discretionary powers, but those policies must be flexible, not rigid. The "flexibility rule", as I call it here, is nearly a century old. Over time, it has become part of the furniture of judicial review: often used, rarely examined. That neglect has led to confusion, on display in recent cases. In this article I try to put the flexibility rule back on a sound footing. I argue, first, that the flexibility rule requires authorities to treat policies merely as rules of thumb. Second, the primary justification for the flexibility rule is neither legislative intent (as courts have said), nor the avoidance of error (as commentators tend to assume); it is the value of participation. Third, and as a result, the flexibility rule ought to apply to policies governing the use of prerogative and other non-statutory powers, as well as to policies governing the use of statutory powers.
\end{abstract}

KEYWORDS - Policies, rules, fetter, participation, flexibility

\section{THREE QUESTIONS}

An official who has a discretionary power may adopt a policy as to its exercise, but that policy must be flexible, not rigid. This rule is a branch of the principle against fettering discretion, which I will call the "flexibility rule". The flexibility rule is now nearly a century old. Over time, the rule has become part of the furniture of judicial review: often used, but rarely examined. ${ }^{1}$ That neglect has led to confusion,

^Associate Professor, University of Oxford; Garrick Fellow and Tutor, Brasenose College. For comments I am very grateful to Nick Barber, Alison Young, and two anonymous reviewers.

${ }^{1}$ There have been only three substantial articles published about the flexibility rule (and indeed about the principle against fettering discretion): H Molot, 'The Self-Created Rule of Policy and Other Ways of Exercising Administrative 
on display in recent cases. In this article, I try to put the flexibility rule back on a sound footing, by answering three questions.

One question is about the scope of the flexibility rule: does the flexibility rule apply widely or narrowly, to policies that govern either statutory or non-statutory powers, or only to policies that govern statutory powers? That question can only be answered by considering another question: what is the rule's justification? In other words, why are rigid policies prohibited and flexible policies permitted? The Supreme Court in $R$ (Sandiford) $v$ Secretary of State for Foreign and Commonwealth Affairs ${ }^{2}$ thought that specific legislative intent justifies the flexibility rule. As a result, it thought that the rule should apply only to policies that govern statutory powers. In Section III, I argue that the Court answered both questions incorrectly. The rule's justification is not specific legislative intent, so there is no cause to draw the rule's boundaries narrowly.

Commentators have tended to justify the flexibility rule on a different basis, namely, the importance of avoiding error. ${ }^{3}$ Policies sometimes fail to reflect the merits of particular cases. Rigidity makes it impossible for officials to correct for these flaws. So, the argument goes, rigid policies should be prohibited. Because avoiding errors is important in both the statutory and non-statutory context, this argument favours a wide flexibility rule. I agree that the flexibility rule should apply widely. But I disagree that error-avoidance justifies the rule. A flexible policy may lead to more errors than a rigid policy, for one thing. A rigid policy also promotes efficiency and predictability, which may be more important than error-avoidance. I set out these criticisms in Section IV.

Courts look to legislative intent to justify the flexibility rule, while commentators look to error-avoidance. My proposal, which I set out

Discretion' (1972) 18 McGill LJ 310; D Galligan, 'The Nature and Function of Policies Within Discretionary Power' [1976] PL 332; C Hilson, 'Judicial Review, Policies and the Fettering of Discretion' [2002] PL 111.

2 [2014] UKSC 44, [2014] 1 WLR 2697 ("Sandiford").

${ }^{3}$ See the references at notes $49-51$. 
in Section $\mathrm{V}$, is that the rule's justification can instead be found in its doctrinal context, and specifically its relationship with the requirement of a fair hearing. Rigid policies do not allow a person affected by a decision to participate in the process by which that decision is made. Flexible policies do. Because the law almost always requires participation in some form, the law should almost always require flexibility. Moreover, because participation is of intrinsic value, flexibility is of value, too. And because participation is of value in both the statutory and prerogative context, the flexibility rule should apply in both contexts also.

The questions about scope and justification are entangled with a third question: what is a flexible policy, as opposed to a rigid policy? This is a question about the types of policies that the flexibility rule permits and prohibits. It is a question about the rule's content, in other words. The content question is the most fundamental of my three questions. Without some idea of what flexible and rigid policies are, it is hard to say much about when and why flexible policies should be permitted and rigid policies prohibited. So I will start with this third question, in the next section. There I will draw on work in jurisprudence to show that flexible policies are best thought of as rules of thumb, and rigid policies as strict rules.

Finally, I should be clear about the scope of my analysis. My interest is strictly the treatment of policies in English common law. As a result, I will not discuss the treatment of policies under the European Convention on Human Rights. ${ }^{4}$ Nor will I have much to say about the common law's treatment of related forms of fettering (eg, by contract). I will also leave aside the doctrine of legitimate expectations. Much has already been written about the perceived

${ }^{4}$ Flexibility is thought to be particularly important when a Convention right is at stake, because a one-size-fits-all approach is unlikely to be proportionate: $R(P) v$ Secretary of State for the Home Department [2001] EWCA Civ 1151, [2001] 1 WLR 2002, at [99]-[106]; but cf Hesham Ali (Iraq) $v$ Secretary of State for the Home Department [2016] UKSC 60. 
tension between that doctrine and the flexibility rule ${ }^{5}$, including by $\mathrm{me}^{6}$, and there is no need to go over familiar ground. My selectivity is partly motivated by considerations of space. That is not my only motivation, however. I believe it is time that the flexibility rule received more attention. The scope, justification, and content of the rule are interesting questions in their own right. They deserve a full analysis, on their own terms. There are hidden depths to the flexibility rule, well worth exploring; or so, anyway, I hope to show.

\section{FLEXIBILITY}

I will begin where the flexibility rule begins, with $R v$ Port of London Authority, ex $p$ Kynoch Ltd ${ }^{7}$. The Port Authority was permitted to build wharves in the Port of London. It also had a power to grant licences for various purposes. The Authority adopted a policy not to license others to do what it could do itself, ie, build wharves in the Port of London. When Kynoch applied for a licence to do exactly that, the Authority refused. Kynoch sought judicial review of the refusal. It argued that the Authority did not bring 'an open mind to bear on the application'8. Bankes LJ distinguished two kinds of case. An authority acts lawfully if it tells an applicant that 'after hearing from him it will in accordance with its policy decide against him, unless there is something exceptional in his case'. But an authority acts unlawfully if, by adopting its policy, it refuses 'to hear any application of a

${ }^{5}$ See, eg, C Hilson, 'Policies, the Non-Fetter Principle and the Principle of Substantive Legitimate Expectations' [2006] JR 289; P Craig, 'Legitimate Expectations: A Conceptual Analysis' (1992) 108 LQR 79, pp. 89-92.

${ }^{6} \mathrm{~F}$ Ahmed and A Perry, 'The Coherence of the Doctrine of Legitimate Expectations' 73 CLJ 61, pp. 80-2.

${ }^{7} R v$ Port of London Authority, ex p Kynoch Ltd [1919] 1 KB 176 (CA) ("Kynoch"). There were forerunners to the modern flexibility rule, eg $R v$ Walsall Justices (1854) 24 LTOS 11.

${ }^{8}$ Kynoch [1919] 1 KB 176, 181.

${ }^{9}$ Kynoch [1919] 1 KB 176, 184. 
particular character by whomseover made'10. Because the Port Authority had considered the particulars of Kynoch's application, it acted lawfully.

The flexibility rule originated in Kynoch, but the leading case is now British Oxygen Co $v$ Minister of Technology ${ }^{11}$. The Board of Trade had a discretionary power to make grants for equipment purchases, but it adopted a policy not to make a grant for any purchase of less than $£ 25$. British Oxygen had purchased a large number of oxygen cylinders, each costing just under $£ 20$. British Oxygen was denied a grant by the Board, based on the policy. Lord Reid said that ' $\mathrm{t}] \mathrm{the}$ general rule' is that 'anyone who has to exercise a statutory discretion must not "shut his ears to an application"'12. An authority must 'always [be] willing to listen to anyone with something new to say'13. Since the Board of Trade had 'carefully considered"14 British Oxygen's application, the Board acted lawfully.

I take three points from Kynoch and British Oxygen:

1. An official may have a policy, but she must be willing to depart from her policy in particular cases.

2. An official must consider, and be responsive to, all the merits of particular cases.

3. A policy may make a difference to the authority's decisionmaking.

The connection between the first two points is important. It is not enough for a policy to include a closed list of "exceptional circumstances", which if established justify departing from a policy. A policy must be open to ad hoc exceptions, in particular cases, if the official considers that the merits of those cases favour a different decision. As The Judge Over Your Shoulder says: 'while it is lawful ... for decision-makers to have a policy, they should nevertheless direct their

\footnotetext{
${ }^{10}$ Kynoch [1919] 1 KB 176, 184.

${ }^{11}$ British Oxygen Co v Minister of Technology [1971] AC 610 (HL) ("British Oxygen").

${ }^{12}$ British Oxygen [1971] AC 610, 625.

${ }^{13}$ British Oxygen [1971] AC 610, 625.

${ }^{14}$ British Oxygen [1971] AC 610, 625.
} 
minds to the facts of the particular case and be prepared to make exceptions' ${ }^{\prime 15}$. The third point is rarely made explicit, but it is obvious on reflection. After all, it would be absurd if the law permitted officials to have policies, but insisted that those policies be redundant or irrelevant.

Later cases have confirmed these three points many times. In $R v$ Home Secretary, ex $p$ Venables and Thompson ${ }^{16}$, Lord Browne-Wilkinson described an official's continuing obligation to take into account all relevant considerations:

[A statutory power] must be exercised on each occasion in the light of the circumstances at that time. In consequence, the person on whom the power is conferred cannot fetter the future exercise of his discretion by committing himself now as to the way in which he will exercise his power in the future. He cannot exercise the power nunc pro tunc. By the same token, the person on whom the power has been conferred cannot fetter the way he will use that power by ruling out of consideration on the future exercise of that power factors which may then be relevant to such exercise. ${ }^{17}$

In $R v$ North West Lancashire Health Authority ${ }^{18}$, Hidden J made clear that an official must always return to the merits of a case:

It is proper for an authority to adopt a general policy [as to medical treatment] for the exercise of ... an administrative discretion, to allow for exceptions from it in 'exceptional circumstances' and to leave those circumstances undefined ... provided that the policy ... requires each request for treatment to be considered on its individual merits. ${ }^{19}$

${ }^{15}$ The Judge Over Your Shoulder (Government Legal Department 2016) 35.

16 [1988] AC 407 (HL) ("Venables and Thompson").

${ }^{17}$ Venables and Thompson [1988] AC 407, 496-7.

18 [2000] 1 WLR 977 (CA) ("North West Lancashire Health Authority").

${ }^{19}$ North West Lancashire Health Authority [2000] 1 WLR 977, 991. 
There are many similar statements in the case law. ${ }^{20}$ Academic commentary is to the same effect. ${ }^{21}$ Indeed, there has been no substantial change to the content of the flexibility rule in the past century.22

Repetition notwithstanding, the three points I mentioned seem to put officials in a difficult position. Officials are not entitled to disregard the merits of a case. Nor are they required to disregard their policies. They are meant to attend to both the merits of particular cases and to their policies. How are officials to manage this feat? The question can be reframed as a paradox. Absent a policy, an official will do as she thinks the merits of each case favours. So, if a policy makes a difference, it can only be by leading the official to act contrary to the merits of a case. But this is precisely the difference a policy may not make (according to 1 and 2). It would seem to follow that there is no lawful difference a policy could make - and yet, it is not unlawful for a policy to make a difference (according to 3 ). That is the paradox. A solution would take the form of an explanation of the difference that policies may lawfully make.

It is tempting to try to solve the paradox as follows. There will be merits and demerits of the act that a policy prescribes. The policy should be thought of as an additional merit of that act. When deciding

${ }^{20}$ See eg Lavender \& Son Ltd $v$ Minister of Housing and Local Government (1969) 1 WLR 1231 (QB), 1240-41; In re Findlay [1985] AC 318 (HL) 336 (Lord Scarman); Secretary of State for the Home Department $v$ R (S) [2007] EWCA Civ 546, [2007] INLR 450, at [50] (Lord Carnwath).

${ }^{21}$ See eg SA de Smith, J Jowell, AP Le Sueur, CM Donnelly, I Hare, De Smith's Judicial Review ( $7^{\text {th }}$ edn, Sweet \& Maxwell 2013) 9-004; HWR Wade and CF Forsyth, Administrative Law (11 ${ }^{\text {th }}$ edn, OUP 2014) 271-2.

${ }^{22}$ The content of the rule has, however, been clarified in several ways. For example, it is now settled that policies must be flexible in practice not just in form: North West Lancashire Health Authority [2000] 1 WLR 977, 993. For a discussion of the incentives for officials to evade this requirement, see L Pottie and L Sossin, 'Demystifying the Boundaries of Public Law: Policy, Discretion, and Social Welfare' (2005) 38 UBCLR 147, pp. 154-5. There is some question whether Stringer $v$ Minister of Housing and Local Government [1970] 1 WLR 1281 ("Stringer") marked a divergence between two ways of treating policies. See text at notes 24-26 below. 
what to do, the official will consider all the merits, including the policy. The policy will therefore make a difference to the official's decision-making, but in a way that respects the requirement to decide on the merits. At first, this may seem like an elegant solution to the paradox. ${ }^{23}$ And at one time, it even had some support in the case law. ${ }^{24}$ It turns out to be a poor solution, though. There are two ways to interpret the proposal, both of them problematic. On one reading, a policy is a genuine merit of the act it prescribes, treated as such. That would mean that an official creates a reason by adopting a policy. But reasons cannot be conjured into existence like this. ${ }^{25}$ The merits of an act do not change by fiat. On another reading, a policy is not actually a merit of the act it recommends, but should be treated as if it were. In that case, the proposed solution is no solution at all. By deciding based on a policy, an official would not be deciding based on the (genuine) merits of a case. She would simply be treating an irrelevant consideration as if it were a relevant consideration.

The solution I favour is very different, but no more complicated. Policies are rules. ${ }^{26}$ Rules are of different types. And the solution to the paradox lies, I claim, in the difference between two types of rules.

${ }^{23}$ Galligan, 'Nature and Functions', pp. 348-50; M Elliott, Beatson, Matthews, and Elliott's Administrative Law ( $4^{\text {th }}$ edn, OUP 2011), 168ff; P Craig, Administrative Law ( $7^{\text {th }}$ edn, Sweet \& Maxwell 2012), $\$ 18-013$.

${ }^{24}$ Stringer [1970] 1 WLR 1281.

${ }^{25}$ Policies are meant to be based on the merits of actions. But, if a policy itself counted as a merit, then the policy would pull itself up by its own bootstraps. There is a similar concern with respect to plans, intentions, and other sorts of commitments. See eg M Bratman, Intention, Plans, and Practical Reason (Harvard University Press 1987), 24-7, 86-7; B Verbeek, 'Rational Self-Commitment' in F Peter and H Bernhard-Schmidt (eds), Rationality and Commitment (OUP 2007) 1602.

${ }^{26}$ Commentators sometimes distinguish between policies (permissible) and rules (impermissible). See eg Galligan, 'Nature and Functions', pp. 350-2. But a rule is just a general norm, and so rules include policies, as recognised in British Oxygen [1971] AC 610, 625. The useful distinction is between rules that are strict and not strict. I discuss that distinction in A Perry, 'Acceptance, Rules, and Reasons' (DPhil thesis, University of Oxford 2012). 
Some rules are strict rules. Whenever a strict rule applies, it settles what is to be done. No matter what you might think of the merits of following the rule in a particular case, the rule insists you do as it says. Many everyday rules are strict rules. Here is an example from the philosopher Geoffrey Warnock:

Consider ... an actual rule of cricket - say that six balls, and no more, are to be delivered from each end in turn. ... [U]mpires do not, on each occasion, when bowlers have bowled six balls, bring the over to an end because they see, on each occasion, good reason to do so. There are in fact plenty of cases in which, from the batsman's or bowler's or even spectator's point of view, it would be an excellent thing to have more than six balls; but the fact is that the merits of such cases do not come into it. ${ }^{27}$

Umpires do not bring the over to an end because they believe the merits of the case favour doing so. Indeed, sometimes umpires are confident the merits favour continuing on. They bring the over to an end anyway. The 'question is removed from the sphere of judgement on the particular merits of the case'28.

Not all rules are strict. Some rules yield - ie, they cease to require anything - if you are sufficiently confident that the merits of a case do not favour doing as the rule says. Strict rules are the usual preoccupation of legal scholars, but rules that are not strict are more common in everyday life. They include recipes, style guidance, and driving directions. If you are confident that this striped shirt will look good with this plaid tie, then you can set aside the rule against matching stripes with plaid. If you are confident that 'a paragraph will better fit the flow of an argument if it discards the usual topic sentence' 29 , then your customary 'allegiance to the rule [against doing

${ }^{27}$ G Warnock, The Object of Morality (Methuen \& Co Ltd 1971), 64-65.

${ }^{28} \mathrm{G}$ Warnock, The Object of Morality 65 . For similar examples, see eg HLA Hart in Essays on Bentham (OUP 1982), 158; J Raz, Practical Reason and Norms (2 ${ }^{\text {nd }}$ edn, Princeton University Press 1990), 75.

${ }^{29}$ F Schauer, Playing by the Rules: A Philosophical Examination of Rule-Based DecisionMaking in Law and Life (OUP 1991), 4. 
so] comes to an end' ${ }^{30}$. Rules that are not strict have a familiar name: we call them rules of thumb. ${ }^{31}$

A rule of thumb 'establishes a confidence level necessary for taking actions inconsistent with the rule' ${ }^{\prime 32}$, as Frederick Schauer says. The confidence levels associated with rules of thumb vary. One rule of thumb might yield when you are more-confident-than-not that the merits of a case do not favour following the rule. Such a rule settles what is to be done if your own 'calculations provide no answer' ${ }^{33}$. At the other end of the spectrum is a rule of thumb that yields only when you are certain that the merits of a case do not favour following the rule. This sort of rule settles what is to be done in most cases - though not all cases. Faced with overwhelming evidence that the rule will lead you astray in a particular case, you will be confident enough to set the rule aside. That is what separates even a stringent rule of thumb from a strict rule, which never yields.

I think that the flexibility rule requires policies to be treated as rules of thumb, rather than as strict rules. Thought of this way, the flexibility rule requires that a policy capable of being formulated as follows:

"Official so and so will decide such and such ..."

must be understood to have an implicit rider of the form:

".. unless she is sufficiently confident that the merits of a case favour a different decision".

${ }^{30}$ Schauer, Playing by the Rules, p. 4.

${ }^{31}$ There is a great deal of terminological disagreement about "rule of thumb". Joseph Raz uses the term somewhat idiosyncratically to describe a type of (what I am calling) strict rule, which is distinguished by its justification as a time- or laboursaving device: Raz, Practical Reason and Norms 59-62. Others use the term to mean something like a reminder of a reason. See eg A Goldman, Practical Rules (CUP 2003), 14-19. My usage is largely consistent with Schauer's. He defends his choice in Playing by the Rules, p. 105 n. 36.

${ }^{32}$ Schauer, Playing by the Rules, p. 108.

${ }^{33}$ Schauer, Playing by the Rules, p. 108. 
The attraction this proposal is that it neatly resolves the paradox I described. Consider British Oxygen. Recall that the Board has a policy of refusing grants for purchases of less than $£ 25$. If that policy is a strict rule, then the policy will not yield, even when it plainly contradicts the merits of a case. That is precisely what the flexibility rule prohibits. By contrast, if the Board's policy is a rule of thumb, then the Board will be willing to set aside the policy if it is satisfied that the merits of a case favour making a small grant. The Board will take into account all the merits, as the flexibility rule demands. But, when the Board's deliberations provide no clear answer, the policy will settle what is to be done. The merits will matter, and the policy will matter. The paradox is avoided.

More fully, flexible policies can make a lawful difference to decision-making in two ways. Suppose that official $X$ must choose between two options, $A$ and $B$. Absent a policy, $X$ will $A$ if she is moreconfident-than-not that $A$ is best, and $B$ if she is more-confident-thannot that $B$ is best. Now, suppose that $X$ has the least stringent sort of rule of thumb. It says:

" $X$ ought to $A$, unless she is more-confident-than-not that the merits of a case do not favour $A$."

This policy will resolve impasses in deliberation. If $X$ thinks that the merits of $A$ and $B$ are impossible to determine; or if $X$ has no information about the merits of $A$ and $B$; or if $X$ thinks the merits of $A$ and $B$ are evenly balanced - then her policy will settle what is to be done, in favour of $A$. If the least stringent rule of thumb makes a difference in this way, then so do more stringent rules of thumb.

Some rules of thumb make a difference in a second way, by raising the level of confidence needed to take some decision. Suppose that $X$ 's policy says:

" $X$ ought to $A$, unless she is clearly satisfied that the merits of a case do not favour $A$."

If $X$ is more-confident-than-not that $B$ is better than $A$, without being fully satisfied that $B$ is better, then her policy will settle what is to be done, again in favour of $A$. The policy overrides her doubts about Aing. In this way, the policy makes a difference, even though there is no deliberative impasse. 
In summary, Kynoch and British Oxygen place officials in a difficult position. They may have regard to a policy, but must have regard to the merits of cases. To manage this feat, officials should not treat policies as merits of the acts they prescribe, to be weighed alongside all the other pros and cons. Nor should they treat policies as strict rules, which never yield. They should treat policies as rules of thumb, and thus as tools to resolve deliberative impasses and to override doubts, which can still be set aside when it seems clear that the merits of a case run contrary to the policy.

\section{LEGISLATIVE INTENT}

With my account of flexibility in place, I turn to the justification and scope of the flexibility rule. My starting point is Sandiford, in which both issues were considered. Sandiford is only the second time the Supreme Court (or House of Lords) has discussed the flexibility rule at length (the first being British Oxygen). As Kevin Costello says, Sandiford is 'probably the most interesting decision ... [about] fettering in over 35 years' 34 . Thus far, the case has received little attention from scholars, so I will describe it in some detail. ${ }^{35}$

Ms Sandiford was arrested at an airport in Indonesia when cocaine was found in her luggage. She was convicted of drug trafficking offences and sentenced to death. Ms Sandiford is a British citizen, so she asked the Foreign Secretary to help pay for the legal costs of challenging her conviction and sentence. The Foreign Secretary could have granted the request by exercising the Crown's discretionary power to make ex gratia payments. He declined, however, because he

${ }^{34} \mathrm{~K}$ Costello, 'The Scope of the Rule Against Fettering in Administrative Law' (2015) 131 LQR 354, 354.

${ }^{35}$ As far as I know, Sandiford has only been discussed in two short (but very helpful) notes: Costello, 'The Scope of the Rule Against Fettering in Administrative Law' and B Huntley, 'The Rule Against Fettering in the Context of the Prerogative' [2015] JR 86. See also CJS Knight, 'A Framework for Fettering' [2009] 14 JR 73, pp. 74-5. 
had a policy not to pay for the legal costs of any British citizen facing any criminal charge abroad. Ms Sandiford applied for judicial review of that refusal. The Foreign Secretary had a rigid policy, she argued, and had failed to decide her case on its merits. In doing so, she said, he fell afoul of the flexibility rule.

Ms Sandiford would have had a strong case, had the power to make ex gratia payments been a statutory power. ${ }^{36}$ It was certainly arguable that the Foreign Secretary's policy was inflexible. And the flexibility rule plainly applies to policies governing statutory powers (the powers in Kynoch and British Oxygen, say, were statutory powers). However, the Crown's power to make ex gratia payments is a nonstatutory power ${ }^{37}$, not a statutory power. So, the question naturally arose: does the flexibility rule apply to policies governing the use of non-statutory powers, as well as statutory powers?

The question might have seemed easy before Sandiford. Long ago the GCHQ case established that exercises of prerogative powers are generally amenable to judicial review. ${ }^{38}$ The usual assumption since has been that, if the exercise of a power is reviewable, the type of power is irrelevant to the available grounds of review. No court has clearly said that any other ground of review (ie, any ground other than the flexibility rule) applies only with respect to statutory powers. ${ }^{39}$

\footnotetext{
${ }^{36}$ Although the Foreign Secretary did consider aspects of Ms Sandiford's case: Sandiford [2014] UKSC 44, [2014] 1 WLR 2697, at [67]-[73].

${ }^{37}$ The power to make ex gratia payments is called a 'prerogative power' in Sandiford by the Court. But it is actually both a non-statutory and non-prerogative power, ie, what is sometimes called an 'administrative power'. See $R$ (New London College) $v$ Secretary of State for the Home Department [2013] UKSC 51, at [28] (Lord Sumption); A Perry, 'The Crown's Administrative Powers' (2015) 131 LQR 652, 658,660 . Nothing important turns on the distinction between prerogative and administrative powers for the purposes of this article.

${ }^{38}$ Council of Civil Service Unions v Minister for the Civil Service [1985] 1 AC 374 (HL) ("CCSU").

${ }^{39}$ Lord Diplock was cautious in CCSU about whether exercises of non-statutory powers should be reviewable for reasonableness: CCSU [1985] 1 AC 374, 411. But there is no longer room for doubt, as Sandiford itself makes clear: Sandiford [2014] UKSC 44, , [2014] 1 WLR 2697, at [65].
} 
Also, before Sandiford, courts tended to assume that the flexibility rule applies with respect to both kinds of power. ${ }^{40}$

Nonetheless, the Supreme Court held in Sandiford that the flexibility rule does not apply with respect to non-statutory powers. Lord Carnwath and Lord Mance gave the lead opinion. ${ }^{41}$ They said:

The basis of the statutory principle is that the legislature in conferring the power, rather than imposing an obligation to exercise it in one sense, must have contemplated that it might be appropriate to exercise it in different senses in different circumstances. But prerogative powers do not stem from any legislative source, nor therefore from any such legislative decision, and there is no external originator who could have imposed any obligation to exercise them in one sense, rather than another. ${ }^{42}$

It follows, according to their lordships, 'that prerogative powers have to be approached on a different basis from statutory powers' 43 . Specifically, 'there is no necessary implication that a blanket [ie, rigid] policy is inappropriate, or that there must always be room for exceptions' ${ }^{\prime 4}$, with respect to non-statutory powers, unlike with respect to statutory powers.

Two questions are intertwined here. One is the aforementioned scope question. The other is about the justification for the flexibility rule: why should rigid policies be prohibited, and flexible policies permitted? Lord Mance and Lord Carnwath attempt to determine the

\footnotetext{
${ }^{40}$ See $R v$ Criminal Injuries Compensation Board, exp RJC (1978) 122 Sol Jo 95 (DC) (non-statutory compensation scheme); Re Dunn's Application for Judicial Review [2010] NIQB 54 (QB) [14] (prerogative of mercy); $R v$ Chief Constable of the North Wales Police, ex $p$ Thorpe [1999] QB 396 (CA) 410-11 (non-statutory power to disclose criminal convictions to the public). But in $R$ (Elias) $v$ Secretary of State for Defence [2006] EWCA Civ 1293, [2006] 1 WLR 3213 the Court of Appeal held that the flexibility rule did not apply with respect to a non-statutory compensation scheme. Surprisingly, counsel in Sandiford did not raise RJC, Re Dunn, or Thorpe.

${ }^{41}$ Lord Sumption gave a separate opinion to similar effect. See especially Sandiford [2014] UKSC 44 [83].

${ }^{42}$ Sandiford [2014] UKSC 44, [2014] 1 WLR 2697, at [61].

${ }^{43}$ Sandiford [2014] UKSC 44, [2014] 1 WLR 2697, at [62].

${ }^{44}$ Sandiford [2014] UKSC 44, [2014] 1 WLR 2697, at [62].
} 
rule's scope by determining its justification. Let me try to reconstruct their reasoning.

In the block quotation, above, their lordships start this way:

1. Legislative intent justifies the flexibility rule in the statutory context.

2. Legislative intent is absent in the non-statutory context. Indeed, the intent of any 'originator' is absent in that context.

Both 1 and 2 can be true and the flexibility rule can be justified in the non-statutory context, as long as the justification for the flexibility rule in the non-statutory context is something other than an originator's intent. So, to reach their conclusion, their lordships need to assume that:

3. Nothing else justifies the flexibility rule in the non-statutory context, ie, nothing other than the legislature's or an originator's intent.

Now their conclusion follows:

4. There is no justification for the flexibility rule in the nonstatutory context.

This is the complete argument, as I understand it. It purports to answer both the scope and justification questions. I will call it "the legislative intent argument".

The legislative intent argument is deeply flawed. Suppose we grant 1 for the sake of argument. 2 is obviously correct. That leaves 3 . What is to be said in favour 3? I can think of two possibilities. First, if the only justification for imposing duties on the use of any power is an originator's intent, then 3 would be true. But this is wrong, of course. Courts are not the originators of non-statutory powers, but courts impose common law obligations as to the use of non-statutory powers. ${ }^{45}$ Second, if a ground of review must have the same basis in every context in which it is available, then again 3 would be correct.

${ }^{45} \mathrm{~A}$ point accepted by all sides in the ultra vires debate: eg D Oliver, 'Is the Ultra Vires Rule the Basis of Judicial Review?' and C Forsyth, 'Of Fig Leaves and Fairy Tales: The Ultra Vires Doctrine, the Sovereignty of Parliament and Judicial Review', both in C Forsyth (ed), Judicial Review and the Constitution (Hart 2000). 
However, the same ground of review can have different justifications in different contexts. ${ }^{46}$ Think of Wednesbury reasonableness review. In non-statutory contexts, the basis for this ground is the common law. It is also possible that its basis in the statutory context is legislative intent. I cannot think of any other argument for 3 , so I am inclined to reject it, and so to regard 4 as unsupported.

Here is a possible objection. All that the previous paragraph shows, my objector will say, is that the courts could develop the common law to prohibit rigid policies in the non-statutory context. To change the law in that way would require a good reason, though, and no such reason is obvious. That is precisely what distinguishes reasonableness from the flexibility rule, my objector will argue. There is good reason to use the common law to extend reasonableness review to the nonstatutory context, but no good reason to extend the flexibility rule. Thus, in the non-statutory context, the flexibility rule has a possible constitutional basis, but no normative basis.

To show why the objection is unsound, I need to turn to 1 , ie, the claim that legislative intent is the basis of the flexibility rule in the statutory context. When Parliament confers a discretionary power, it rarely explicitly says that it intends that power to be used flexibly. So, how are we supposed to know that Parliament has this intention? Perhaps the idea is that Parliament must have this intention, given its intention to confer a discretionary power. ${ }^{47}$ That might sound plausible, until we distinguish two things we can say about Parliament's intentions. Here is one:

"Parliament does not intend to limit the use of such and such power itself."

Here is another, quite different proposition:

${ }^{46}$ See eg M Elliott, The Constitutional Foundations of Judicial Review (Hart 2001) 180.

${ }^{47}$ I think this is what Lord Carnwath and Lord Mance have in mind in Sandiford. They say it is a 'necessary implication' of Parliament's conferral of a discretionary power that Parliament intends that power to be used 'in different senses in different circumstances' (at [62]). 
"Parliament intends the use of such and such power not to be limited."

When Parliament confers a discretionary power, it follows that Parliament does not intend to limit the use of that power, such that it can be used in only one way. But it does not follow that Parliament intends the use of that power not to be so limited. Why would Parliament choose not to limit a power itself, without also choosing the use of that power not to be limited? For either of two reasons: because Parliament wants someone else to choose how to limit that power, or because Parliament wants someone else to choose whether to limit that power. This "someone else" will most likely be the official to whom the power has been given. None of this is hypothetical. Sometimes, Parliament really does intend not to limit a power itself, while also intending that power to be limited by an official. ${ }^{48}$

At this point, I have said that it is rare for Parliament to explicitly say that it intends a discretionary power to be used flexibly. And I have said that this intention cannot be inferred from the intention to confer the power. What, then, justifies 1? Only one plausible answer remains: Parliament is presumed to intend a discretionary power to be used flexibly. Now, I have no quarrel with this answer. But it is fatal to the legislative intent argument. For if we are entitled to presume that Parliament intends for discretionary powers to be used flexibly, it can only be because there are good reasons for discretionary powers to be used flexibly, which Parliament can be expected to act on. If there are good reasons for discretionary powers to be used flexibly, then a fortiori there are good reasons for non-statutory discretionary powers to be used flexibly. Thus, 1 can be defended, but only in a way that provides a normative basis for the flexibility doctrine in the non-

${ }^{48}$ See, eg, R (Nicholds) v Security Industry Authority [2007] 1 WLR 2067 (QB), at [61]-[62]; R (Thebo) v Entry Clearance Officer Islamabad [2013] EWHC 146 (Admin), at [31]. For discussion and older examples, see SH Bailey, Cases, Materials, and Commentary on Administrative Law (4th edn, Sweet \& Maxwell 2005), 494-5. 
statutory context. In other words, 1 can be defended, but only in a way that undermines 3 , and in turn 4 .

In summary, it is tempting to think that specific legislative intent justifies the flexibility rule. That is what the courts think. In fact, if legislative intent justifies the rule, it is presumed legislative intent doing the work. The courts also think that the rule applies only in the statutory context. However, whatever reasons justify the presumption as to legislative intent will also justify the flexibility rule in the nonstatutory context. So, if the flexibility rule is justified, it is justified in both contexts. Of course this does not tell us whether the flexibility rule is justified, or what its justification might be. These are the points to which I now turn.

\section{ERROR-AVOIDANCE}

I want to consider a different argument for the flexibility rule, one that favours a wide scope for the rule. Roughly, the idea is that policies should be flexible so that officials can avoid erring when deciding particular cases. I do not know of anyone who makes precisely this argument, but many scholars endorse similar ideas, including Denis Galligan ${ }^{49}$, Chris Hilson ${ }^{50}$, and the editors of de Smith's Judicial Review ${ }^{51}$. I will first set out the argument in its strongest form, then assess it.

As rules, policies are general. They apply to a class of case, which share some feature (eg, that they are applications for a licence to build a wharf). If a policy is well-designed, it will reflect an official's judgement as to what the merits of that class of case generally favour. However, these cases will not be identical. There will be cases to which the policy applies, but which ought not on their merits to be treated as the policy says. Policies will be overinclusive, in other

${ }^{49}$ Galligan, 'Nature and Functions', pp. 350-1.

${ }^{50}$ Hilson, 'Judicial Review, Policies and the Fettering of Discretion', pp. 112-4. These remarks are endorsed in Elliott, Administrative Law, p. 174.

${ }^{51}$ De Smith et al, De Smith's Judicial Review, $\$ 9-005$. 
words. Overinclusiveness cannot be avoided through more careful drafting. Even a narrow policy, full of nuances and qualifications, will not produce the "right" answer in every case. The problem is that our cognitive capacities and predictive powers are limited. Here is Plato's Stranger on the imperfection of laws (and the same could be said of any rule):

[Law] can never issue an injunction binding on all which really embodies what is best for each: it cannot prescribe with perfect accuracy what is good and right for each member of the community at one time. The differences of human personality, the variety of men's activities and the inevitable unsettlement attending all human experience make it impossible for any art whatsoever to issue unqualified rules holding good on all questions at all times. ${ }^{52}$

Policies prescribe a single course of conduct. By contrast, the cases to which they apply are varied and multifarious. It is inevitable that there is some mismatch between what policies require and what the particulars of cases demand.

If a policy is rigid, then an official cannot set the policy aside when it is overinclusive. She cannot correct for the policy's flaws. By contrast, if a policy is flexible, then the official can dispense with the policy when (she thinks) it would be a mistake in the circumstances not to do so. This sort of 'rectification of law in so far as law is defective on account of its generality' 53 is what Aristotle termed equity. And equity, Aristotle says, is the duty of a rule-applying officials in any particular case:

[W] hen the law states a general rule, and a case arises under this that is exceptional, then it is right, where the legislator owing to the generality of his language has erred in not covering the case, to correct the omission by a ruling such as the legislator himself would have given if he had been present there, and as he would have enacted if he had been aware of the circumstances ....54

52 Plato, Statesman (JB Skemp trans., Bristol Classical Press 1952), at 294a-b. See also F Schauer, Profiles, Probabilities, and Stereotypes (Harvard University Press 2003), 28-9.

${ }^{53}$ Aristotle, Nicomachean Ethics (JAK Thomson trans., Penguin 1977) ), at 1137b.

${ }^{54}$ Aristotle, Nicomachean Ethics, paras. 1137a-b. 
Rigid policies insist on a one-size-fits-all approach. Flexible policies allow officials to correct for the excesses of the policy, and to tailor their decisions to the needs of particular cases. Rigidity is equity's foe, flexibility its friend.

At this point, a new argument for the flexibility rule takes form. Let us say that a decision is an "error" if it is at odds with the merits of a case. Then the argument goes:

1. Flexible policies avoid more errors than rigid policies.

2. It is important to avoid errors.

3. So, rigid policies should be prohibited.

I will call this "the error-avoidance argument", though it could also be framed in terms of the advancement of equity or accuracy. Avoiding error is no less important in the non-statutory context than the statutory context. That means the error-avoidance argument favours a wide flexibility rule, one which applies to policies that govern either non-statutory or statutory powers.

There are two obvious objections to the error-avoidance argument, to which there is a possible response. But this response meets with two further objections, from which I think there is no recovery.

The first objection goes to 1, above. Suppose that an official is a perfect judge of the merits of particular cases. Whenever she disagrees with a policy, it is the official who is right. In this scenario, a flexible policy does indeed minimize errors, by giving free reign to the official's superior judgement. But of course no official will be a perfect judge of the merits, and many officials will be quite a bit worse than perfect. Imagine an official who is unskilled, careless, or prejudiced. She is forgetful, distracted, or overburdened. Her policy, meanwhile, was designed over time, when deliberative resources were abundant. It was designed in isolation from the temptations of individual cases. Perhaps it was also designed in a large organisation, where responsibility for policy-creation was given to those best able to do the job, allowing expertise to be pooled and shared. When the official disagrees with the policy, it is probably the policy that is right. In this not implausible scenario, the official commits fewer errors by relying 
on her policy, instead of on her own inferior judgement. Here, rigidity minimizes error. ${ }^{55}$

The second objection is aimed at 2. Although accuracy is important, other things matter, too. Sometimes they even matter more than accuracy. Consider some of the virtues of rigid policies. They are very efficient. ${ }^{56}$ Deliberative resources like time and energy need to be expended only once, when the policy is designed, rather than in each case (except to determine that the policy is applicable). ${ }^{57}$ The saved resources can be devoted to other tasks. Decisions in particular cases can be made more quickly, which applicants will appreciate. A rigid policy also makes decisions more predictable. Applicants will know the likely outcome of their applications (assuming the policy is published), which helps them plan their lives. ${ }^{58}$ Applicants will know what information and arguments are relevant when they make their submissions. That speeds up decisionmaking even more. Predictability also benefits the government. For example, if the Board of Trade knows that it will not issue any grants for small equipment purchases, then it can plan the rest of its budget accordingly.

${ }^{55}$ Error-reduction is a traditional justification for rule- (or policy-) based decision-making. See eg JS Mill, System of Logic, Ratiocinative and Inductive (first published 1843, Kessinger Press 2004), 617-618; C Schneider, 'Discretion and Rules: A Lawyer's View' in K Hawkins (ed), The Uses of Discretion (OUP 1992) 72; R Baldwin, Rules and Government (OUP 1995), 13-4.

${ }^{56}$ See eg J Jowell, Law and Bureaucracy (Dunnellen 1975), 19-20; Schauer, Playing by the Rules, pp. 145-9; Schneider, 'Discretion and Rules', p. 77

${ }^{57}$ As Whitehead said, 'operations of thought are like cavalry charges in battle they are strictly limited in number, they require fresh horses, and they must only be made at decisive moments'. AN Whitehead, An Introduction to Mathematics (OUP 1948), 42.

${ }^{58}$ Merchandise Transport Ltd $v$ British Transport Commission [1962] 2 QB 173 (CA), 193 (Devlin LJ) (a policy 'makes for uniformity of treatment and it is helpful to the industry and to its advisers to know in a general way how particular classes of applications are likely to be treated'). Compliance with the rule of law is of value for a similar reason: see eg J Raz, 'The Rule of Law and its Virtue' in J Raz, The Authority of Law (OUP 1979). 
A rigid policy better promotes efficiency and predictability than a flexible policy, but (I am assuming for the moment) a rigid policy also leads to more errors. Errors are the price of efficiency and predictability, in other words. This will not be a price worth paying if the increase in errors is large and the stakes are high (if an "error" is an incorrect deportation decision, say). But it probably is a price worth paying if the increase in the number of errors is small or if the stakes are low, especially if deliberation costs are high or a stable basis for planning is crucial. When the price is worth paying - when there are things more important than avoiding errors - then rigid policies are again likely superior to flexible policies.

So far, I have made two objections to the error-avoidance argument. Rigid policies may minimize errors. And rigid policies may have advantages that matter more than avoiding error. Either objection shows that, relative to accuracy, efficiency, and predictability, there is sometimes more to be said for a rigid policy than for a flexible policy. Why, then, should rigid policies be banned?

Here is how an error-avoidance theorist might answer. The objections so far attack a straw man, she will say. No one would claim that the flexibility rule is perfect. It is a rule, after all, and I have already admitted that rules are overinclusive. Sometimes, a rigid policy will be desirable, and the flexibility policy will prohibit the policy anyway. But such cases are rare. What matters is the general run of cases. Do flexible policies generally lead to fewer errors than rigid policies? Surely they do, the error-avoidance will say. Is error-avoidance generally more important than efficiency and predictability? Yes again, she will insist. So, in general, flexible policies are superior to rigid policies. The flexibility rule is not perfect, but it gets most cases right. And that, the error-avoidance theorist will conclude, is justification enough for the rule. (To be clear, I do not endorse this line of reasoning. I present it for the sake of argument.)

One way to meet this response is to note that the generalizations on which the error-avoidance theorist depends are empirical claims, with no obvious support. Whether a flexible or rigid policy leads to fewer errors depends on (i) the reliability of the official who applies the policy, and (ii) the reliability of the policy itself. Whether erroravoidance is more important than efficiency and predictability 
depends on factors like (iii) the time and energy it would take to think about the merits of particular cases; (iv) the other uses of these deliberative resources; (v) the effect of flexibility on planning and coordination; and (vi) the stakes involved. Taken together, (i)-(vi) will favour different policies in different administrative contexts. Sometimes a flexible policy will be superior. Sometimes a rigid policy will be superior. I doubt we can say anything much more general than that.

There is another way to meet the response. Let us suppose that rigid policies are generally superior to flexible policies. What follows is merely this: if courts must prohibit either rigid policies or flexible policies, then they should prohibit rigid policies. But of course courts have a third option. Instead of laying down a rule, courts could let officials choose the sort of policy to have (rigid or flexible), subject to Wednesbury reasonableness review. This is, after all, how courts treat the choice between having a policy simpliciter and not having a policy at all. They leave that choice to officials, on condition that they choose reasonably. Once this alternative to the flexibility rule is pointed out, I think its appeal is obvious. Whether an official should adopt a rigid or flexible policy depends on a variety of pros and cons (ie, considerations like (i)-(vi) above). Normally, courts leave complicated, context-sensitive choices like these to officials. Should they not also leave the choice between a rigid and a flexible policy to officials?

My interlocutor might say "no" because she thinks that officials cannot be trusted with the choice between rigid and flexible policies. But this answer creates a tension within the error-avoidance argument. We assumed, for the sake of argument, that flexible policies are generally superior to rigid policies. This implies that officials are reliable judges of the merits of particular cases. Now we are being asked to assume that officials are unreliable judges of the sort of policies they should have. There is no out-and-out contradiction here. It is possible for an official to be both a good judge of the merits of a case, but a bad judge of the sort of policy to adopt, because she does not appreciate her own ability to judge the merits of particular cases. It is possible - but implausible. It is implausible that officials are good judges of the merits of particular cases who consistently do 
not appreciate what good judges of the merits they are. Officials are not so peculiarly, predictably self-effacing.

In summary, the error-avoidance argument is flawed in at least four ways. First, rigid policies may reduce errors more effectively than flexible policies. Second, even when flexible policies better reduce errors, rigid policies may have other, more important advantages. It follows that flexible policies are not always better, and are sometimes worse, than rigid policies. Third, there is no reason to think that flexible policies are generally superior to rigid policies. Finally, even if flexible policies are generally superior to rigid policies, that does not justify a ban on rigid policies, as opposed to letting officials work out for themselves when rigidity is appropriate.

\section{PARTICIPATION}

The legislative intent argument is unsuccessful. The same is true of the error-avoidance argument. We need a new justification for the flexibility rule - but we will need to look in a different direction to find it. The arguments in the last two sections are directed outward, beyond the law of judicial review: the courts have looked to legislative intent, and commentators have looked to the general normative consideration of error-avoidance. I think we would do better to look inward, to the doctrinal context of the flexibility rule, and especially to the requirement of a fair hearing.

Think back to British Oxygen. The Board had a policy not to issue grants for purchases under $£ 25$. Nonetheless, British Oxygen applied for a grant, and the Board provided the company with a hearing. Now consider the following scenario:

Scenario 1

The Board's policy is rigid. The Board is determined to refuse grants for purchases under $£ 25$, no matter what. It has effectively decided all such applications in advance - 'nunc pro tunc', as Lord BrowneWilkinson would have said. ${ }^{59}$ Nothing that British Oxygen could

${ }^{59}$ Venables and Thompson [1988] AC 407, 497. 
say in the hearing would convince the Board to make an exception. Anything it did say would fall on deaf ears.

In this scenario, a hearing takes place, but it is a sham or pretence. It provides the appearance of participation in the decision-making process, but not the reality. Compare a second scenario:

\section{Scenario 2}

The Board's policy is flexible. The Board uses its policy to resolve impasses in deliberation, and perhaps to override doubts about an application. But the Board is open to persuasion. What British Oxygen says in the hearing can make all the difference. If the company convinces the Board that the merits are on its side, then it will influence the Board's decision, and win its grant.

In this second scenario, the hearing is no sham. British Oxygen may fail to convince the Board to make an exception to its policy. But if the company fails, it will be because the merits were not clearly on its side, not because it was ignored.

If there is to be a hearing, then it should be meaningful, not for show. This point holds true even if a hearing should not have been held in the first place. In an ideal world, perhaps the Board would not have granted British Oxygen a hearing. But it did. At that point, the Board became obliged to ensure the hearing was a genuine opportunity for participation in the decision-making process. To do otherwise - to go through the motions of hearing from an applicant, even though the decision had already been made - would be disingenuous, bordering on duplicitous. It would be wasteful, given the time and resources involved. And it would be disrespectful to the applicant.

The law presumes that powers should be exercised in a way that is procedurally fair. ${ }^{60}$ What procedural fairness requires varies with the

${ }^{60} R \vee$ Home Secretary [1994] 1 AC 531 (HL) 560 (Lord Mustill). There are certainly cases in which there is no right to make representations, such as cases involving emergencies ( $R v$ Secretary of State for Transport, ex $p$ Pegasus Holdings (London) Ltd [1988] 1 WLR 990) and decisions to carry out a search $(R v$ Leicester Crown Court, ex p Director of Public Prosecutions [1987] 1 WLR 1371). But these cases are exceptions. As Wade and Forsyth say, 'where the grant of a fair hearing is 
context, of course. Even if you are affected by a decision, and have something to say about the issues that are relevant to that decision, you often do not have a right to an oral hearing, to rely on counsel, to cross-examine witnesses, etc. But one thing is clear: you almost always have a 'right to make representations' ${ }^{\prime} 1$ in some form. The bare opportunity to make representations - 'the core of the duty to act fairly" 62 - is all that I mean by a "hearing" and "participation" in this section.

At this point, we have a new argument for the flexibility rule:

1. You are almost always entitled to a hearing.

2. A hearing should be a real opportunity to participate in the decision at issue.

3. A hearing is a real opportunity to participate in a decision only if relevant policies are flexible.

4. So, policies should almost always be flexible.

This argument takes an existing feature of judicial review - the presumptive requirement of a hearing - as a fixed point, and reasons to the conclusion that the flexibility rule is justified. The argument is internal to the law of judicial review: it begins and ends with doctrine. I will call it "the participation argument".

The participation argument says that policies should be flexible whenever there is a right to make representations. Procedural fairness applies with respect to non-statutory powers. ${ }^{63}$ That means the participation argument generates a clear answer to the scope question: the flexibility rule should apply widely, to policies that govern non-statutory as well as statutory powers. Seen this way, the

consistent with the exercise of a legal power, the law leans strongly in its favour' (Administrative Law, p. 421).

${ }^{61} R v$ Home Secretary [1994] 1 AC 531 (HL) 560 (Lord Mustill). Lord Mustill was speaking of cases that adversely affected some interest, but the same could now be said of benefit cases: see $R v$ Secretary of State for the Home Department, ex $p$ Fayed (No 1) [1998] 1 WLR 763 (CA).

${ }^{62} \mathrm{~J}$ Auburn, J Moffett, A Sharland, Judicial Review (OUP 2013), at $\$ 6.04$.

${ }^{63}$ CCSU 1985] 1 AC 374, 411-2; Lewis v Attorney General of Jamaica [2001] 2 AC $50(\mathrm{PC}) 80$. 
mistake in Sandiford was to consider the flexibility rule in isolation. That led the Court to determine the rule's applicability without reference to the applicability of other grounds of review, including procedural fairness.

I do not claim that the participation argument argument is original. I think something like the argument was assumed in both Kynoch and British Oxygen. Bankes LJ in Kynoch writes of the difference between cases in which an official tells an applicant what its policy is 'without refusing to hear [the] applicant' 64 , and cases in which the official decides 'not to hear any application of a particular character by whomsoever made' 65 . Lord Reid in British Oxygen said that an official must be 'always willing to listen to anyone with something new to say'66, before adding that there does not "need be an oral hearing' ${ }^{67}$. In both cases, the flexibility rule is explained against the backdrop of a right to a fair hearing. Many recent cases rationalize the rule along similar lines. ${ }^{68}$ But at some point after British Oxygen, commentators largely stopped relating the flexibility rule to hearings. ${ }^{69}$ So the participation argument is not a discovery; it is a re-discovery.

With administrative hearings front and centre, it is natural to compare flexible policies to rules that matter in other sorts of hearings. I think the closest analogy is to the burden of proof at trial. At trial, the trier of fact is expected to reach a decision based on the

${ }^{64}$ Kynoch [1919] 1 KB 176, 184 (emphasis added).

${ }^{65}$ Kynoch [1919] 1 KB 176, 184 (emphasis added).

${ }^{66}$ British Oxygen [1971] AC 610, 625 (emphasis added).

${ }^{67}$ British Oxygen [1971] AC 610, 625 (emphasis added).

${ }^{68}$ eg $R v$ Secretary of State for the Environment, exp Brent LBC [1982] QB 593 (CA) 644 (per Ackner LJ) ("Brent").

${ }^{69}$ There are some notable exceptions. Costello, in 'The Scope of the Rule Against Fettering in Administrative Law', distinguishes between a 'statutory duty' analysis of the flexibility rule and a 'duty to act judicially' analysis, where the duty to act judicially includes a duty to provide a fair hearing (pp. 356-7). Sandiford endorsed the statutory duty analysis, while Costello thinks the rule is supported by both rationales. De Smith et al classify the flexibility rule as part of procedural fairness but, as the authors note, their choice is an unusual one (De Smith's Judicial Review, at $\$ 9-002)$. 
admitted evidence. But the scales are not evenly set. One party bears the burden of proof on the overall issue or on a sub-issue. If that party fails to discharge its burden, then that issue will be decided against them. In an administrative hearing, a flexible policy imposes a like burden on the applicant. In British Oxygen, for example, the Board will decide on the merits, if possible. But it is up to British Oxygen to persuade the Board that the merits are on its side. If the company fails to do so, or does not even try, then the Board will resort to its policy - just as the trier of fact will decide against a party that fails to discharge its burden. Seen this way, a flexible policy is a device for placing a "burden of persuasion" on applicants, with a hearing best seen as an opportunity for the applicant to discharge that burden. Just as it would defeat the purpose of a trial to impose an irrebuttable burden of proof on a party at trial, it would defeat the point of an administrative hearing to impose a burden of persuasion that could not be satisfied (ie, to adopt a rigid policy).

I have set out the core of my case for the flexibility rule; now let me consider two objections. The first objection starts from the observation that the participation argument is inherently limited. The argument purports to justify the flexibility rule insofar as there is a right to a fair hearing. But sometimes there is no right to a fair hearing. So, even if the argument is correct, it does not justify the flexibility rule in its current range of application. Why is this a problem? The worry cannot be that my argument favours a change in the law. That would be nothing to shy away from. Also, there are few cases in which there is no right to make representations, and as a result few cases that would not be covered by the flexibility rule under my proposal. Further, the "change" I favour is one that keeps faith with the origins of the flexibility rule in Kynoch and British Oxygen. The worry must rather be that rigid policies are objectionable even when there is no right to make representations, so the flexibility rule should apply even when there is no such right, contrary to what I have proposed.

At this point I want to force my objector to clarify her position. Does she think that rigid policies are generally objectionable, even when there is no right to make representations? If so, she thinks there is an alternate justification for the flexibility rule (ie, a non- 
participation-based justification). But the onus is surely on her to identify that justification, given the lengthy discussion of the leading alternatives in the last two sections. Or, does she think that rigid policies are sometimes objectionable, even when there is no right to make representations? If that is the thought, then I agree with the objector, up to a point. A rigid policy can be disastrous, for reasons that have nothing to do with participation. A rigid policy could lead to far more errors than a flexible policy, for example, with no real gain in predictability or efficiency. However - and here is where the objection fails - the fact that rigid policies are sometimes objectionable (for reasons of error-avoidance, say) does not justify a general ban on rigid policies. Also, policies that are too rigid may run afoul of other doctrines, namely, reasonableness and (if applicable) proportionality.

So much for the first objection. The second objection to the participation argument is that is takes the requirement of a fair hearing for granted. It does not try to justify that requirement. As a result, the argument does not justify the flexibility rule in any deep, doctrine-independent way. Now, put like this, I do not think the objection is anything to worry about. The fair hearing requirement is an integral part of judicial review. It is here to stay. Also, the requirement has strong intuitive support. Whether or not we make its normative foundations explicit, we feel that a fair hearing is important. So, as I say, were there nothing else to the objection, I would leave matters there. But there is more. The difficulty (my objector will go on to say) is that there is a tension between my conclusions in the last section and my reliance on the fair hearing requirement here. One argument - perhaps the main argument - for the fair hearing requirement is instrumental. An official is supposed to make a better decision if she hears from the person affected. But did I not argue, in the last section, that officials may make worse decisions if they try to decide on the merits of a case, as opposed to simply relying on a policy? That seems to commit me to rejecting the instrumental argument for a fair hearing. And if I earlier rejected the main rationale for a fair hearing, I cannot help myself now to the assumption that the fair hearing requirement is justified. Or so the objection goes. 
I accept that it would be difficult to maintain that a hearing is usually valuable for instrumental reasons, and at the same time to doubt that a flexible policy is usually valuable for the same reasons. I can sidestep the objection, though, as long as a fair hearing is of intrinsic value. And so, I think, it is. I cannot prove that point here. It is too large a topic. But the intrinsic value of participation is not seriously in dispute. Also, for my purposes, it is enough that there is some intrinsic value to participation; it does not matter precisely what that value is. So let me simply mention the two ways in which I think it is most plausible that participation is of intrinsic value. ${ }^{70}$

First, participation respects human dignity. It does so by treating those affected by a decision as if they should have a say in how their lives go. In $R$ (Osborn) v Parole Board ${ }^{71}$, Lord Reed said that:

Respect entails that [those who are significantly affected by administrative decisions] ought to be able to participate in the procedure by which the decision is made, provided they have something to say which is relevant to the decision to be taken. ${ }^{72}$

His lordship quoted Jeremy Waldron, who described the 'crucial dignitarian idea' of treating those to whom a rule is to be applied as 'capable of explaining themselves'73. The idea is powerful, I think. You are not an object to be acted upon, and should not be treated as if you were. You are someone who can speak for yourself about the things that affect you. Letting you participate in the decision-making process acknowledges this.

Galligan thinks that participation is intrinsically valuable for a second reason, namely, the right to self-protection. He says:

${ }^{70}$ For a recent overview of the intrinsic value of hearings (albeit in the criminal law context), see D Meyerson, 'The Moral Justification for the Right to Make Full Answer and Defence' (2015) 35 OJLS 237.

${ }^{71}$ [2013] UKSC 61, [2014] AC 1115, at [68] (“Osborn”).

72 Osborn [2013] UKSC 61, [2014] AC 1115, at [68]. The intrinsic value of a hearing is a consistent refrain in the case law, beginning with Cooper $v$ Wandsworth Board of Works (1863) 14 CBNS 180, 195 (Byles J).

${ }^{73}$ J Waldron, 'How Law Protects Dignity' [2012] 71 CLJ 200, 210. See also T Allan, 'Procedural Fairness and the Duty of Respect' (1998) 18 OJLS 497. 
Just as I may lawfully defend myself against physical attack, I may defend myself against the actions of the state which threaten other aspects of well-being. The idea of self-defence can in this way be extended to cover all my legitimate interests. ${ }^{74}$

Galligan does not try to fully justify his claim that you have a right to protect your interests. He thinks it is 'a foundational principle of political morality"75. But he clearly sees the principle as existing alongside principles of autonomy and individual responsibility. Even if you are not the 'best person to look after [your] own interests' ${ }^{76}$, he says, it is still important that you take 'primary responsibility'77 for protecting those interests. By doing so, you take charge of your fate.

These remarks are admittedly sketchy, but they go some way towards showing that participation is of intrinsic value. To my mind, they also help show what is objectionable about rigid policies. By adopting a rigid policy, an official forecloses the possibility of participation in the decision-making process. She thereby signals disrespect to applicants. She says, in effect: you are not worth hearing from, on this matter that affects you so much. And she sends a message of disempowerment, saying: you may not take responsibility for yourself, nor may you defend yourself. For the same reasons that participation is inherently valuable, rigid policies are inherently problematic.

Let me draw things together. I set out the core of an argument for the flexibilty rule. I considered two objections to that argument, the first of which I rejected, and the second of which I accepted in part. The argument I ultimately endorse goes like this: The law generally requires officials to be willing to hear from those affected by their decisions. There are good reasons for this requirement, dignity and self-defence among them. Also, once a hearing is granted, rightly or wrongly, there are good reasons for an official to treat the hearing seriously, which means being willing to take into account what was

\footnotetext{
${ }^{74}$ D Galligan, Due Process and Fair Procedures (OUP 1996) 141.

${ }^{75}$ Galligan, Due Process and Fair Procedures, 142.

${ }^{76}$ Galligan, Due Process and Fair Procedures, 141.

77 Galligan, Due Process and Fair Procedures, 141.
} 
said during the hearing when the decision is made. From this perspective, there is nothing wrong with an official having a flexible policy, because she will remain responsive to what she hears. But a rigid policy, which precludes consideration of any other factor, is a different matter. A rigid policy amounts to a decision in advance. It makes any hearing held a sham. And sham hearings are intolerable: they are disrespectful, disingenuous, and wasteful; they also undermine the values of dignity and self-defence. So, the law should prohibit rigid policies, insofar as there is a right to a fair hearing.

The participation argument is compatible with both the legislative intent argument and the error-avoidance argument. I do not think that either of those other arguments are successful. But, if one (or both) of them was successful, it would not cast any doubt on the points made in this section. It would simply mean that the flexibility rule has multiple arguments in its favour.

\section{CONCLUSION}

I began with three questions about the flexibility rule. The Supreme Court in Sandiford gave clear answers to two of those questions, about the rule's scope and justification. I think the Court erred in both respects, and I tried to explain why. I also tried to provide better answers to those questions, and to answer a related question about the rule's content. A flexible policy is a rule of thumb, I said. The flexibility rule is justified by the importance of participation. As a result, the rule ought to apply widely, in both statutory and nonstatutory contexts. In addition to explaining what the rule requires, why it matters, and how far it extends, these answers reveal the rule's close connection with another doctrine, namely, procedural fairness. The flexibility rule has been poorly understood, but I hope to have helped place it back on a sound footing.

I have focused on the flexibility rule to the exclusion of some related aspects of judicial review, including the other main branches of the principle against fettering discretion, about delegation and contractual fetters. This was for reasons of space. But I confess that I also doubt that the flexibility rule has much in common with the other branches of the no-fettering principle (other than an overlapping 
subject matter). I am now in a better position to support that intuition. If I am right about how to understand the flexibility rule, then the problem with rigid policies is that they are effectively decisions made in advance, without the opportunity for input by those affected by the decision. This cannot be the problem with delegation and contractual fetters, though, because in neither case is the person affected by the decision necessarily denied the chance to take part in the decision-maing process. Perhaps - and I put it no stronger than that - it would be better to think of delegation, contractual fetters, and rigid policies separately, rather than treating them as parts of a single doctrine.

Let me end by raising a new question. Policies must be flexible, but flexibility is a matter of degree, as I said. At one end of the spectrum is a very flexible policy, which yields whenever an official thinks that the merits of a case favour departing from the policy. At the other end is a nearly rigid policy, which yields only when an official is certain that the merits of a case favour a departure. In between are policies of intermediate degrees of flexibility. What degree of flexibility does the law demand? In truth, I doubt that question has an answer. Indeed, it is not plain that the cases even address it. Here is the real question: what range of flexibility should the law demand or permit? The question is interesting, partly because it is difficult. And it is difficult both because it is unclear whether the law should insist on a uniform degree of flexibility, and because it is unclear what factors bear on the appropriate degree of flexibility, either in general or in a particular case. I intend to return to these matters - but they will have to wait for a different article. 